From the National Veterinary Institute, Oslo, and the University of Tromsø, Institute of Biology and Geology, Department of Ecology, Tromsø, Norway.

\title{
Experimental Elaphostrongylus Cervi Infection in Moose (Alces Alces)
}

\author{
By Gudbrand Stuve and Arne Skorping
}

\begin{abstract}
Stuve, G. and A. Skorping: Experimental Elaphostrongylus cervi infection in moose (Alces alces). Acta vet. scand. 1987, 28, 165-171. - An 8-week-old male moose calf was inoculated with 360 infective third-stage larvae (L3) of E. cervi. The calf started to expel first-stage larvae (L1) of E. cervi in faeces 63 days after inoculation. The highest faecal larval count of $1,920 \mathrm{~L} 1$ per gram faeces was recorded 133 days post inoculation. Clinically, intermittent lameness, mild ataxia and general stiffness were observed over a 3 months' period from day 75 after inoculation. The symptoms were moderate, faded gradually and were not seen during the last three weeks of the observation period. The calf had a good appetite and the bodyweight increased continuously throughout the experiment. On day 202 after inoculation the calf was euthanized and autopsied. Adult E. cervi were found in the epidural space of the central nervous system (CNS) and in skeletal muscles. Oedema, haemorrhages, discolouration and extensive inflammatory reactions were observed in the fat and loose connective tissue of the epidural space between the 5 th cervical vertebra and cauda equina. Nematodes or lesions indicating nematode infestation could not be demonstrated in the leptomeninges or in the neural parenchyma of the CNS. Numerous eggs and larvae of E. cervi associated with moderate pathological changes were observed in the lungs.
\end{abstract}

cervidae; protostrongylidae; prepatence; pathogenesis; pathological changes; CNS.

\section{Introduction}

The protostrongylid nematode Elaphostrongylus cervi Cameron, 1931 occurs endemically in moose (Alces alces) in Southern Norway (Stuve 1986). A considerable proportion of the moose seems to become infected as calves during the first summer season (Stuve 1987).

The pathogenesis of elaphostrongylosis and the manifestation of clinical symptoms are difficult to evaluate in free-ranging moose. A study on the development of this disease can best be made on animals in captivity. The present paper presents the results of an ex- perimental infection of a moose calf with E. cervi.

\section{Materials and methods}

\section{Animals}

A motherless male moose calf was used in the study. The calf was found when $2-3$ days old and immediately brought to the Norwegian College of Veterinary Medicine. The calf was kept indoors to prevent parasite exposure. It was bottle fed with a commercial milk replacer for 5 months and was offered fresh leaves of birch, rowan, aspen and Virginia creeper and later also bilberry 
foliage, raspberry bush, apples and feed concentrates.

For 2 weeks prior to and during the experiment the calf was kept at Dal Research Farm, Heggedal, near Oslo. It was kept indoors during the night but spent the daytime in an outdoor enclosure which was situated inside the fenced meadows of the research farm. No wild cervids had access to the enclosure or its immediate surroundings and the calf was considered not to have become naturally exposed to E. cervi within the enclosure.

Another moose calf, kept together with the calf referred to in the present study, was also infected experimentally with E. cervi. However this calf died 43 days after being inoculated due to causes unrelated to E. cervi infection.

\section{Experimental inoculation}

First-stage larvae (L1) of E. cervi were isolated by baermannisation of faeces from hunted moose originating in Southern Norway and known to be infected with E. cervi. Laboratory-reared terrestrial snails of the species Arianta arbustorum were exposed to approximately 10,000 L1 per 20 snails for 2 h. After 2 months of incubation in terraria at $20^{\circ} \mathrm{C}$, the soft tissue of the snails was gently pressed in a trichinoscopy compressor. Third-stage larvae (L3) of E.cervi were identified and counted with a dissecting microscope. The squashed snails with L3 were removed from the compressor slides with water and collected in a pitcher.

At eight weeks of age, when it weighed 38.5 $\mathrm{kg}$, the calf was given an aqueous suspension of 17 squashed snails containing $360 \mathrm{~L} 3$ of E. cervi by stomach tube.

\section{Clinical and pathological examination}

The general condition and behaviour of the moose calf was recorded daily throughout the experiment. Faecal samples were examined weekly for protostrongylid Ll after baermannisation and for nematode eggs after flotation in saturated $\mathrm{NaCl}$-solution. The body weight was also recorded and venous blood samples were collected into tubes containing heparin. Haematological examination was carried out for haemoglobin- $(\mathrm{Hb})$, packed cell volume (PCV), total red blood cell counts (RBC), and differential and total white blood cell counts (WBC).

The moose calf was euthanized, bled and autopsied 202 days post inoculation of E. cervi L3.

The brain and spinal cord including the meninges, spinal nerves and epidural tissues were carefully removed and examined grossly and with a dissecting microscope for the presence of nematodes. Subcutaneous tissues, fasciae, skeletal muscles, peripheral nerves and lymph nodes were examined carefully for the occurrence of nematodes. Smears of bronchial mucus were examined by light microscopy for the presence of E. cervi L1. Nematodes removed from the tissues were fixed in $70 \%$ alcohol for light microscopic identification.

Specimens from the central nervous system (78), lung (10), peripheral nerves (17), skeletal muscles (5), lymph nodes (5), heart, liver, kidney and spleen were fixed in $10 \%$ neutral buffered formalin, processed routinely and embedded in paraffin. Sections at 5-6 $\mu \mathrm{m}$ were stained with haematoxylin and eosin (HE). Selected sections were in addition stained with van Giesson, periodic acid Schiff (PAS), silver impregnation (Wilder) or Prussian blue.

\section{Results}

The daily handling of the moose calf made him very tame and docile.

The calf started passing Ll of E. cervi in faeces 63 days post inoculation. Fig. 1 shows 
Gudbrand Stuve and Arne Skorping: Experimental Elaphostrongylus cervi infection in moose (Alces alces).

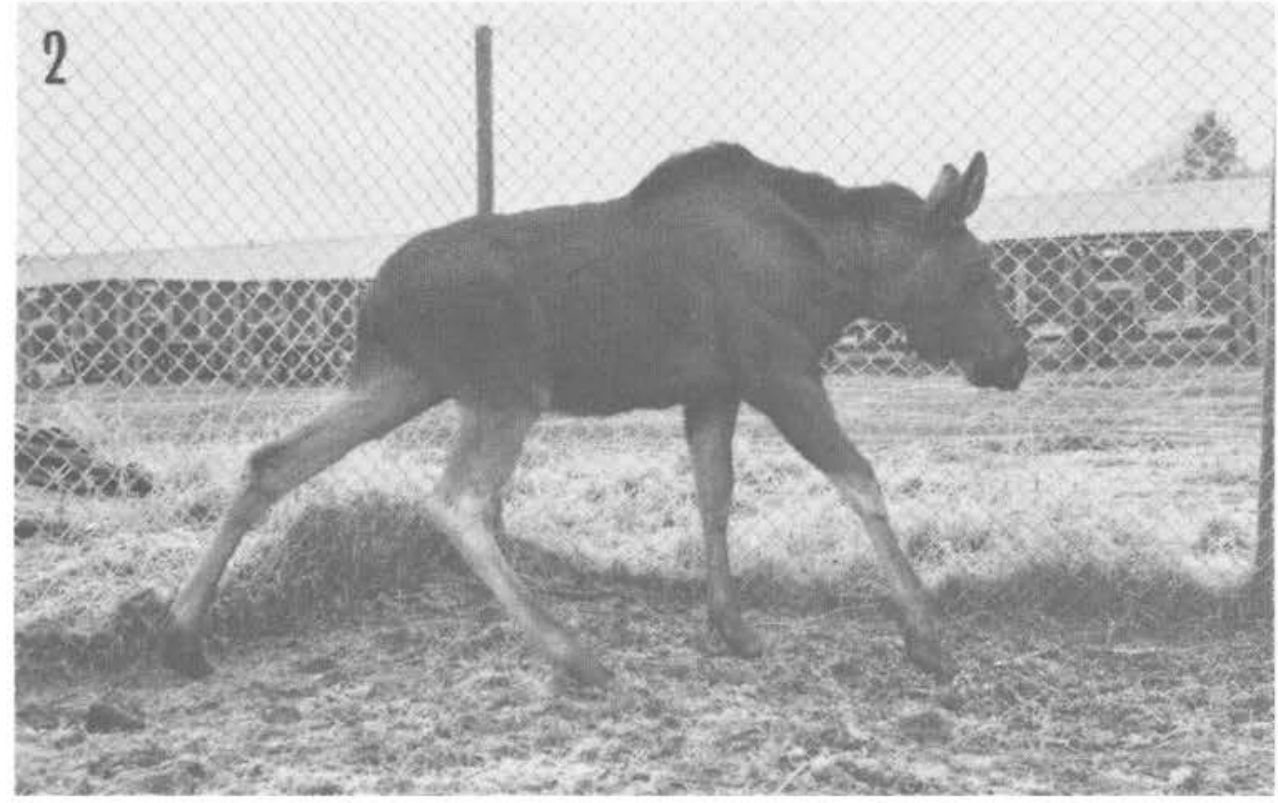

Figure 2. The moose calf on day 119 after inoculation of E. cervi L3.

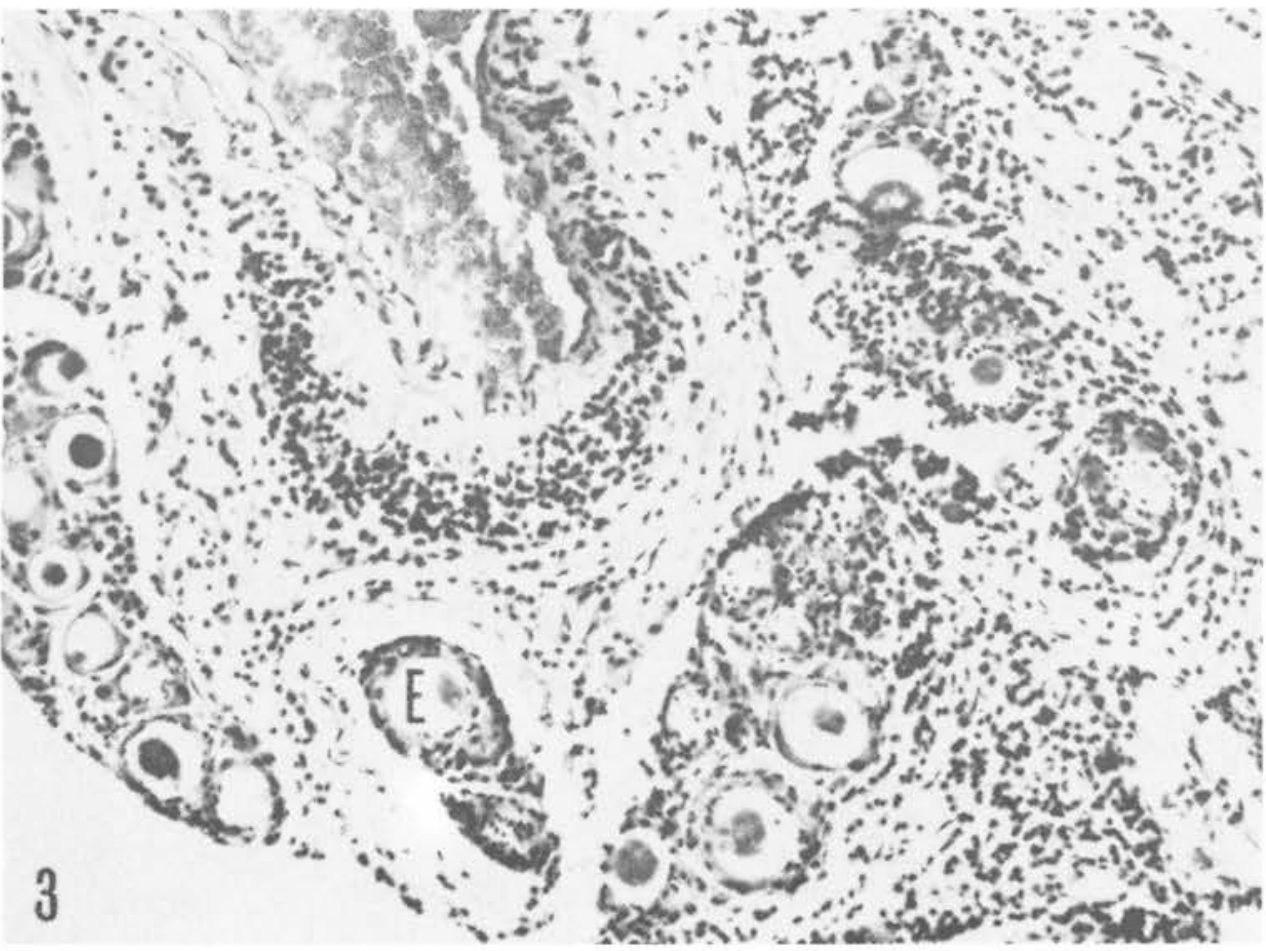

Figure 3. Epidural space. Eggs of E. cervi (E), focal accumulation of granulocytes and mononuclear cells, eosinophil perivascular infiltration, and vascular wall lesions. (HE $170 \times$ ). 


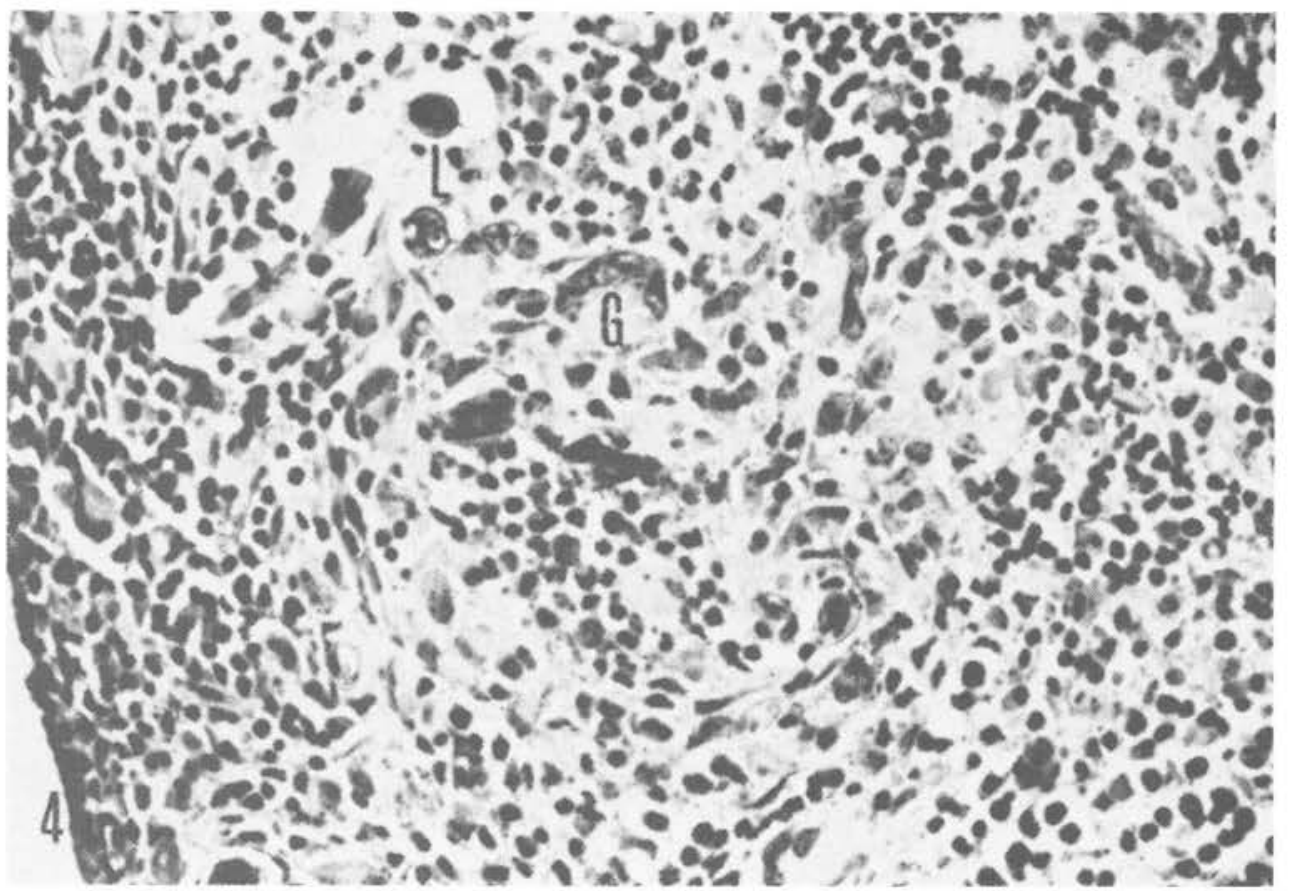

Figure 4. Epidural space. Granuloma containing E. cervi L1 (L) and foreign body giant cells (G). (HE $425 \times$ ).

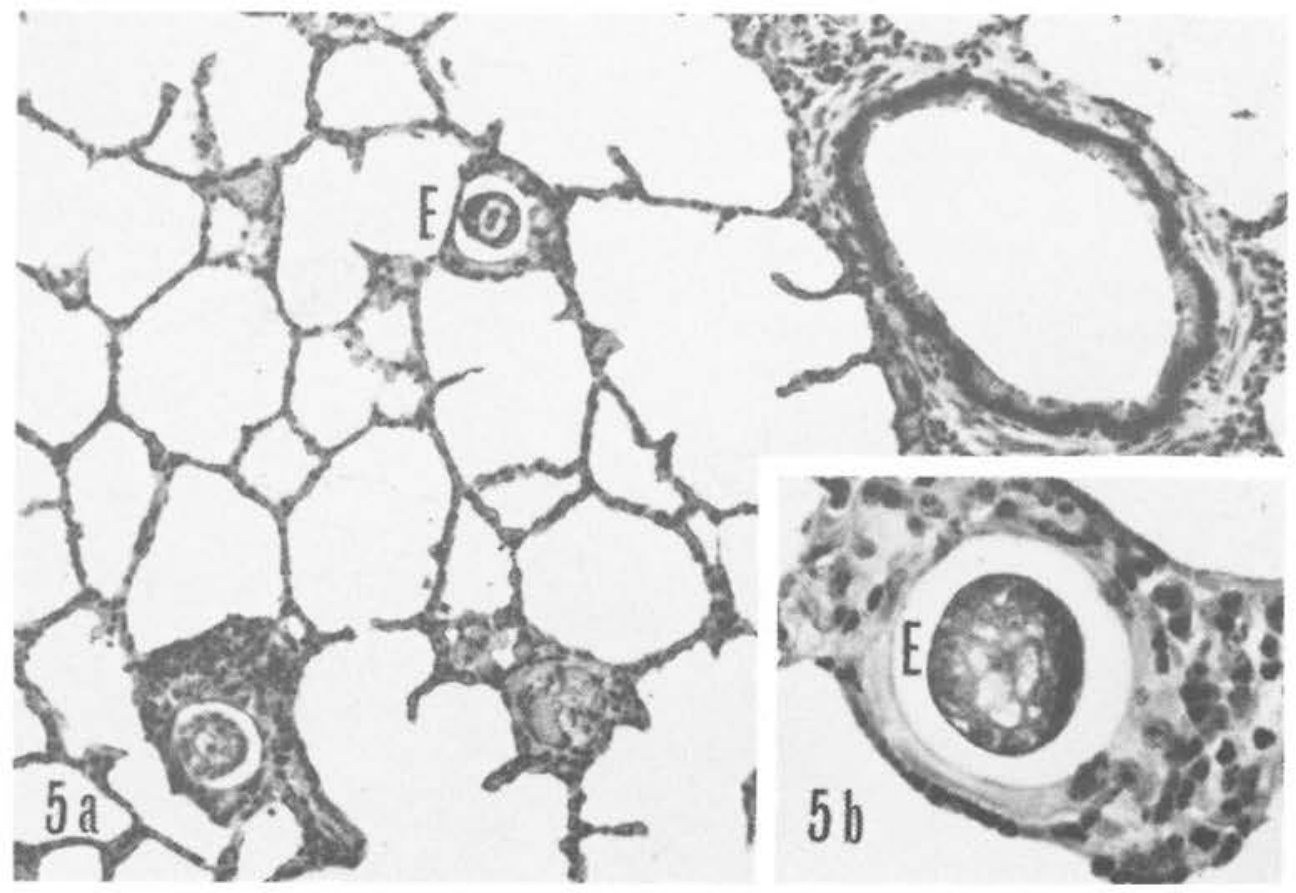

Figure 5a. Lung. Disseminated eggs of E. cervi (E) surrounded by infiltrates of macrophages, neutrophils, and lymphocytes. (HE 170x).

Figure 5 b. Lung. Egg of E. cervi (E) occluding a pulmonary capillary (HE $425 \times$ ). 


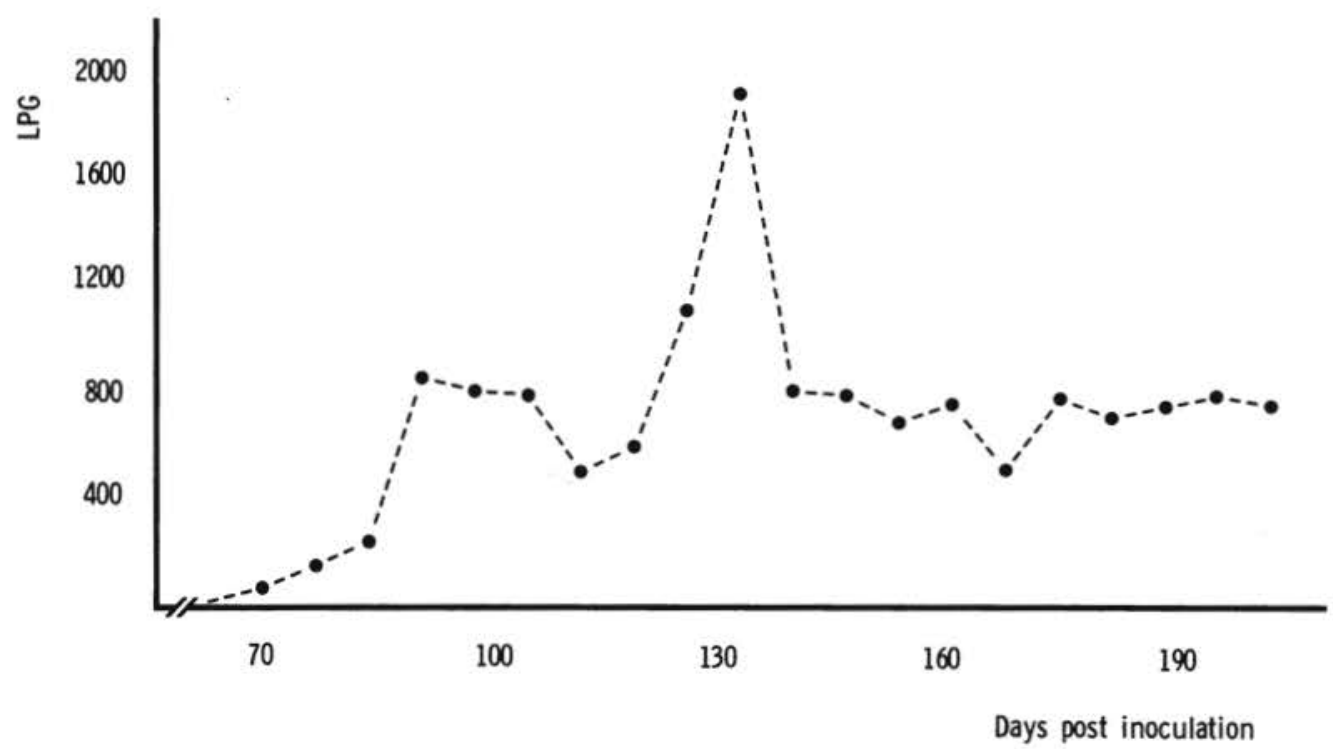

Figure 1. The faecal larval expulsion of the moose calf counted weekly during the experiment. $\mathrm{LPG}=$ larvae per gram faeces .

the faecal larval output during the experiment.

Clinical symptoms consisting of lameness in the right hind leg were observed for the first time 75 days post inoculation. During the following 3 months the calf showed moderate intermittent lameness, alternating between all 4 legs, but occurring most frequently in the hind legs. The general pattern of locomotion was affected, the movements being cautious and the gait shortened, especially when trotting, and there were mild symptoms of ataxia and general stiffness (Fig. 2). The locomotory disturbances were most evident on solid, frozen or rocky ground. Occasionally the calf seemed to be somewhat dull. On the other hand, the appetite was excellent and the calf gained weight continuously throughout the experiment. The locomotory disturbances faded gradually towards the end of the observation period and symptoms were not observed during the last 3 weeks of the experiment.
The haematological examination revealed a slight increase in the relative number of eosinophil granulocytes during the experiment. In the first 5 weeks of the experiment the eosinophil fraction represented $0-1 \%$ of the leucocytes, at 6 weeks post inoculation $6 \%$, and throughout the rest of the experiment it varied between 2 and $9 \%$. The other cellular constituents recorded varied within the normal range $(\mathrm{Hb} 11.5-15.6 \mathrm{~g} / \mathrm{dl}, \mathrm{PCV}$ $33-46 \%$, RBC $4.3-6.1 \times 10^{12} / 1$, WBC 4.6-7.6 × $10^{9} / 1$, neutrophils $27-49 \%$, lymphocytes $50-74 \%$ and monocytes $0-2 \%$ ).

The calf weighed $138 \mathrm{~kg}$ when euthanized. At necropsy 44 nematodes, identified as adult E. cervi, were found, indicating $12 \%$ recovery of the inoculated L3 in the form of adult worms. Thirty-two worms were found in the skeletal muscles and 12 in the epidural space of the vertebral columna.

The adult worms recovered from skeletal muscles were all located in the loose connective tissue of the epimysium or in the 
fasciae of the muscles. Nine E. cervi were found on the left subscapular and brachial muscles, 1 worm was found between the right pectoral muscles, whereas 10 and 12 worms, respectively, were scattered on the muscles of the left and right thigh. Small haemorrhages and a slightly greyish discolouration were demonstrated adjacent to the worms. No lesions were observed in peripheral nerves or lymph nodes.

The worms found within the vertebral columna were all located in the fat or loose connective tissue of the epidural space between the 1st and 9th thoracic vertebra. Oedema, haemorrhages and yellow-brownish discolouration were observed in the epidural space between the 5 th cervical vertebra and cauda equina, being most extensive within the thoracic portion of the vertebral canal. The brain, spinal cord and the leptomeninges appeared normal. Lesions were not observed in the epidural space cranially to the cervical vertebra.

Scattered subpleural and interstitial petechial haemorrhages were observed in the lungs. E. cervi $\mathrm{Ll}$ were present in bronchial mucus. There were no gross changes in other viscera.

Histological examination of epidural connective tissue from the portion between the 5 th cervical vertebra and cauda equina revealed infiltrations with and focal accumulations of granulocytes and mononuclear cells (Fig. 3). Infiltrations with the same cell types were found close to the thoracic spinal nerves and in the outer layer of the dura mater. Eosinophil perivascular infiltrations and vascular wall lesions with eosinophil infiltrations also occurred (Fig. 3). Small veins and lymph vessels were occasionally occluded by thrombotic material. Numerous macrophages containing hemosiderin were found throughout the epidural space. Moreover, characteristic foci with macrophages, neutrophils and giant cells were observed (Fig. 4). These granulomas contained eggs and/or larvae of E. cervi. Eggs in cleavage were occasionally found, being surrounded by moderate mononuclear infiltrates. No histopathological changes could be found in the leptomeninges or in the neural parenchyma of the brain, spinal cord and spinal nerves.

Large numbers of E. cervi eggs (Fig. 5a) and larvae were disseminated throughout the lungs. Eggs in different developmental stages seemed to be located in pulmonary capillaries, causing embolic occlusions. Macrophages, neutrophils and lymphocytes infiltrated the embolic occlusions in which homogenous, eosinophil deposits also were embedded (Fig. 5b). Larvae of E. cervi were seen mainly in alveoli or bronchioli and did not cause reactive changes. A mild muscular hypertrophy occurred multifocally. In spite of the occurrence of numerous eggs and larvae in the lungs the pathological changes observed were generally moderate.

Histological examination of skeletal muscles revealed variable, but generally moderate, infiltrations with eosinophils, macrophages, neutrophils and lymphocytes in the endomysium, epimysium and loose connective tissue adjacent to adult worms. Furthermore, perivascular infiltrations of eosinophils could be demonstrated.

The second moose calf, administered 180 L3 of E. cervi, died 43 days post inoculation due to digestive disturbances, emaciation and polyarthritis. Neither E. cervi nor lesions indicating parasite infestation were found at necropsy of this calf.

\section{Discussion}

The present study shows that E. cervi isolated from moose can be experimentally transferred to moose calves, causing moderate locomotory disturbances. Furthermore, 
epidurally located worms cause extensive pathological changes within the epidural space.

E. cervi has been reported to be located at different sites within the central nervous system (CNS) of moose. Lankester (1977) found E.cervi (transferred experimentally from caribou) within the leptomeninges of the brain and the spinal cord and within the brain ventricles of a moose calf. Steen \& Mørner (1985) also found worms within the leptomeninges of moose. On the other hand, worms and associated pathological lesions were found in the fat and the loose connective tissue of the epidural space by Holt (1982) and Stuve (1987). Unpublished results based on an examination of the entire CNS of 70 moose and the spinal cords of another 140 moose over a 4 years' period also revealed that worms and lesions were confined to the epidural space of the vertebral canal in Southern Norwegian moose (Stuve \& Holt, unpublished results). Thus it seems that the elaphostrongylid species occurring in moose from Southern Norway is incapable of penetrating the dura mater of the host. Furthermore, the natural adhesion of the dura mater to the periost of the cranial bones seems to prevent the worms from entering the cranium.

The taxonomy of the genus Elaphostrongylus, in which the 3 species E. cervi Cameron, 1931, E. panticola Lubimow, 1945 and E. rangiferi Mitskevich, 1958 have been described, has not yet been settled. Based on the view that the latter two species are synonymous with E.cervi (Pryadko \& Boev 1971, Kutzer \& Prosl 1975, Pryadko 1976, Lankester \& Northcott 1979), the species involved in the present study is referred to as E. cervi. However, the epidural location of the elaphostrongylid worms within the CNS, as reported in the present study, compared with the leptomeningeal location reported by Lankester (1977) and Steen \& Mørner (1985), may indicate that either different strains of the same species or even different species of elaphostrongylid worms can occur in moose.

The pathogenicity of E. cervi in moose was considered to be moderate by Stuve (1987). Holt (1982) reported that elaphostrongylosis seemed to cause increased mortality, especially in calves during the winter, whereas Lankester (1977) showed that E. cervi caused severe neurologic disease in experimentally infected moose. The moderate neurologic disturbances observed in the present study were apparently far less extensive than those described by Lankester (1977), or those reported in reindeer suffering from elaphostrongylosis (Ronèus \& Nordkvist 1962, Kummeneje 1974). Lankester (1977) administered 472 L3 and recovered 36 adult worms, of which 10 were found within the leptomeninges of the CNS. The occurrence of severe neurological disturbances in $\mathrm{E}$. cervi infected animals is therefore probably primarily related to the location of the worms within the CNS rather than to the number of worms.

The neurological disorders in the present study did not seem to be due to specific damage of the neural parenchyma. The epidural location of the worms and the associated lesions may, however, have caused a compression of the spinal nerves resulting in functional disturbances. The intermittent lameness may have been caused by worms migrating within the epidural space.

A natural exposure of the moose calf to E. cervi can probably be completely excluded. The calf started shedding $\mathrm{Ll}$ in October. An autoinfection can therefore also be excluded due to the time needed for development of L3 (Skorping \& Halvorsen 1980) and the absence of snails during winter.

Prosl \& Kutzer (1980) have postulated that 
eggs of E. cervi are transported via venous blood or lymph from the sites of the adult worms to the heart and from there via the pulmonary artery to the lungs. The finding of lesions in the epidural space and lungs in the present study corresponds well with this hypothesis. The haemorrhages, vasculitis and thrombosis of small venules and lymphatic vessels in the epidural space might have been caused by female worms penetrating the vascular walls to deposit eggs. The extensive accumulation of hemosiderin within macrophages indicates frequent haemorrhages. Furthermore, the occurrence of numerous disseminated eggs throughout the lungs, where no adult E. cervi occur, and the intravascular location of the eggs, also indicate blood transportation via the pulmonary artery.

The results of the present study indicate that E. cervi infection exerts a moderate pathogenic effect on moose calves. Nevertheless, a similar degree of infection in free-ranging calves with corresponding pathological changes as observed in the present study, might reduce their chance of surviving the harsh Norwegian winter.

\section{Acknowledgement}

This study was financially supported by the Norwegian Agricultural Research Council. We thank Professor O. Helle and Dr. G. Holt for essential help and guidance, Dr. B. Bratberg for guidance regarding the histological examination, the staff at Dal Research Farm, Heggedal for taking good care of the moose calves and the technicians T. Ingebrigtsen and E. Aronsen for assistance with the rearing of snails.

\section{References}

Cameron TVM: On two new species of nematodes from Scottish red deer. J. Helminthol. 1931, 9, 213-216.

Holt G: Påvisning av elaphostrongylose hos elg $\mathrm{i}$ Sør-Norge gir grunn til en viss engestelse. (De- monstration of elaphostrongylosis in moose in Southern Norway gives reason for some anxiety). Jakt, fiske og friluftsliv. 1982, 9, 33-34.

Kummeneje $\boldsymbol{K}$ : Encephalomyelitis and neuritis in acute cerebrospinal nematodiasis in reindeer calves. Nord. Vet.-Med. 1974, 26, 456-458.

Kutzer E, Prosl H: Zur Kenntnis von Elaphostrongylus cervi Cameron, 1931. I. Morphologie und Diagnose. (Contribution to the knowledge of Elaphostrongylus cervi Cameron, 1931. I. Morphology and diagnosis). Wien. tierärztl. M. Schr. 1975, 62, 256-266.

Lankester MV: Neurological disorders in moose caused by Elaphostrongylus cervi Cameron, 1931 from caribou. Proc. 13th North American Moose Conference and Workshop. Jasper, Alberta 1977, 177-190.

Lankester $M V$, Northcott TH: Elaphostrongylus cervi Cameron, 1931 (Nematoda: Metastrongyloidea) in caribou (Rangifer tarandus caribou) of Newfoundland. Can. J. Zool. 1979, 57 , 1384-1392.

Lubimow MP: New worm disease of the brain of deer with unossified antlers. Sbornik nauchoissledovatel'skikh rabot. Laboratory pantovogo olenvodestva Ministerstva sovkhozov SSSR 1945, 1, 225-232. (In Russian).

Mitskevich WJ: Studies on the life cycle of the nematode Elaphostrongylus rangiferi sp. nov. in reindeer. Dokl. Akad.nauk. SSSR 1958, 118, 253-255.

Prosl H, Kutzer E: Zur Biologie und Bekämpfung von Elaphostrongylus cervi. (Biology and control of Elaphostrongylus cervi). Z. Jagdwiss. $1980,26,198-207$.

Pryadko EI: Helminths of cervids. Alma Ata, USSR. Izdatel'stvo Nauka Kazakhskoi 1976. 1-224. (In Russian).

Pryadko EI, Boev SN: Systematics, phylogeny and eyolution of Elaphostrongylinea - nematodes of deer. Izv. Akad. nauk. Kaz. SSSR. Ser. Zool. 1971, 3, 74-85. (In Russian).

Ronèus $O$, Nordkvist M: Cerebrospinal and muscular nematodiasis (Elaphostrongylus rangiferi) in Swedish reindeer. Acta vet. scand. 1962, 3, 201-225.

Skorping A, Halvorsen $O$ : The susceptibility of terrestrial snails to experimental infection with 
Elaphostrongylus rangiferi Mitskevich (Nematoda: Metastrongyloidea). Z. Parasitenkd. 1980, 62, 7-14.

Steen, $M$, Morner $T$ : "Hjärnmask - en ny allvarlig viltsjukdom. ("Brainworm « - a new serious disease of wild game). Svensk jakt 1985, 7/8, 601-603.

Stuve $G$ : The prevalence of Elaphostrontgylus cervi infection in moose (Alces alces) in southern Norway. Acta vet. scand. 1986, 27, 397409.

Stuve G: Elaphostrongylus cervi infection in moose (Alce alces). Prevalence and pathological changes in relation to and season. Acta vet. scand. 1987, 28, 157-164.

\section{Sammendrag}

Eksperimentell infeksjon av elg (Alces whes) thed Elaphostrongylus cervi.

Til en morløs, 2 måneder gammel thet thet

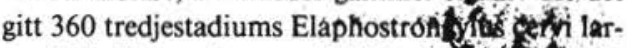

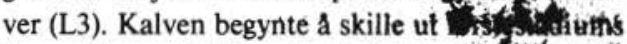
E. cervi larver (L1) med avføringen 63 dinget ettet at den ble podet. Den høyeste larveutskillelsen med 1.920 larver pr. gram feces ble registrert 133 dager etter inokulering. Kalven viste moderate forstyrrelser i bevegelsesmønsteret med intermitterende halthet, noe korte og stive bevegelser og svak ataksi fra den 75 . dagen etter podningen. Symptomene ble observert $\mathrm{i}$ en 3 måneders periode, og ble gradvis svakere mot slutten av denne periaden. De siste 3 ukene før kalven ble avlivet ble det ikke registrert symptomer. Kalven hadde god appetitt og tilveksten var jevn under hele forsøket. Kalven ble avlivet og obdusert 202 dager etter podningen. Kjønnsmodne parasitter ble påvist epiduralt i ryggmargen og i muskulaturen. Patologiske forandringer med ødem, blødninger, misfargning og omfattende betennelsesreaksjoner ble pávist $\mathrm{i}$ fettvevet og det løse bindevevet $\mathrm{i}$ epiduralrommet. Parasitter eller patologiske forandringer ble ikke påvist hverken $\mathrm{i}$ leptomeninger eller netveparenchym. I lungene ble det påvist rikelig med E. cervi egg og larver, men bare moderate patológiske forandringer.

\section{(Ninterind November 15, 1986).}

Reprints may be requested from: O. Gith, Nhtortal Veterinary lnstitute, P. O. Box 8156 Dep., N-0033 Oslo 1, Norway. 